\title{
Geochemistry of Mirny field kimberlites, Siberia
}

\author{
Agashev A.M., ${ }^{1}$ Nakai S., ${ }^{2}$ Serov I.V., ${ }^{3}$ Tolstov A.V., ${ }^{1}$ Garanin K.V., ${ }^{3}$ Kovalchuk O.E. ${ }^{3}$ \\ ${ }^{1}$ V.S. Sobolev Institute of Geology \& Mineralogy, Novosibirsk 630090, Russia (* correspondence: \\ agashev@igm.nsc.ru) \\ ${ }^{2}$ Earthquake Research Institute, The University of Tokyo, Tokyo, Japan \\ ${ }^{3}$ ALROSA Co Ltd., Mirny, Russia
}

\section{Introduction}

Kimberlites are known as incompatible elements and volatile enriched mantle originated rocks which contains a diamond. Geochemical composition of kimberlites is very heterogenic as between closely located pipes and even within one kimberlite body (Agashev et al, 2000). However, kimberlites composing one kimberlite field could be genetically related and formed by single tectonomagmatic episode from the one source. In this study we attempt to find the regularities in variations of geochemical composition of kimberlites within one kimberlite field which could arise from their genetic relationship. Mirny kimberlite field is located in the central part of Siberian craton in the southernmost part of Siberian kimberlite province. Tectonic position of the field is within the Botuobinskaya anticlinal structure, which divides the Tunguss and Vilyui synclises. Mirny field consists of six kimberlite pipes, 2 independent dykes, one satellite pipe and several dikes connected with pipes. Four kimberlite pipes are economical diamond mines. Hence, Mirny kimberlite filed is a good object to systematic study the compositional variations of kimberlites composing the field.

\section{Chemical composition}

Kimberlites of Mirny field are enriched in incompatible trace elements having a solid/liquid distribution coefficient in mantle silicates of approximately zero $(\mathrm{Ba}, \mathrm{Sr}, \mathrm{Nb}$, Ta, $\mathrm{Zr}$, Hf, Th, U and LREE). At the same time they are enriched in trace elements compatible to ultramafic mineralogy such as $\mathrm{Cr}, \mathrm{Ni}$, Sc, and $\mathrm{V}$ and these features are typical for kimberlites. The concentrations of incompatible elements normalized to the PM composition (Fig. 2) have negative anomalies for $\mathrm{Rb}, \mathrm{K}, \mathrm{Zr}$ and positive for $\mathrm{Nb}$, Th or $\mathrm{Ba}, \mathrm{Nd}$ and $\mathrm{Sm}$. This type of distribution was shown to be common for Gr I kimberlites (Smith et al 1985) and plumerelated OIB. The degree of enrichment in incompatible elements is variable between particular pipes and concentrations of LIL elements are most variable. (Fig. 2). Variation in concentrations of LREE and HFS elements in Mirny filed kimberlites are much less comparative to that of LILE. On the plot of $\mathrm{Ba} / \mathrm{Nb}$ and $\mathrm{La} / \mathrm{Nb}$ ratios, Mirny field kimberlites show great scatter in their $\mathrm{Ba} / \mathrm{Nb}$ along the composition of main mantle reservoirs (Hoffman 1997) from values lower than that of HIMU OIB and up to values of EM OIB (Fig. $3)$.

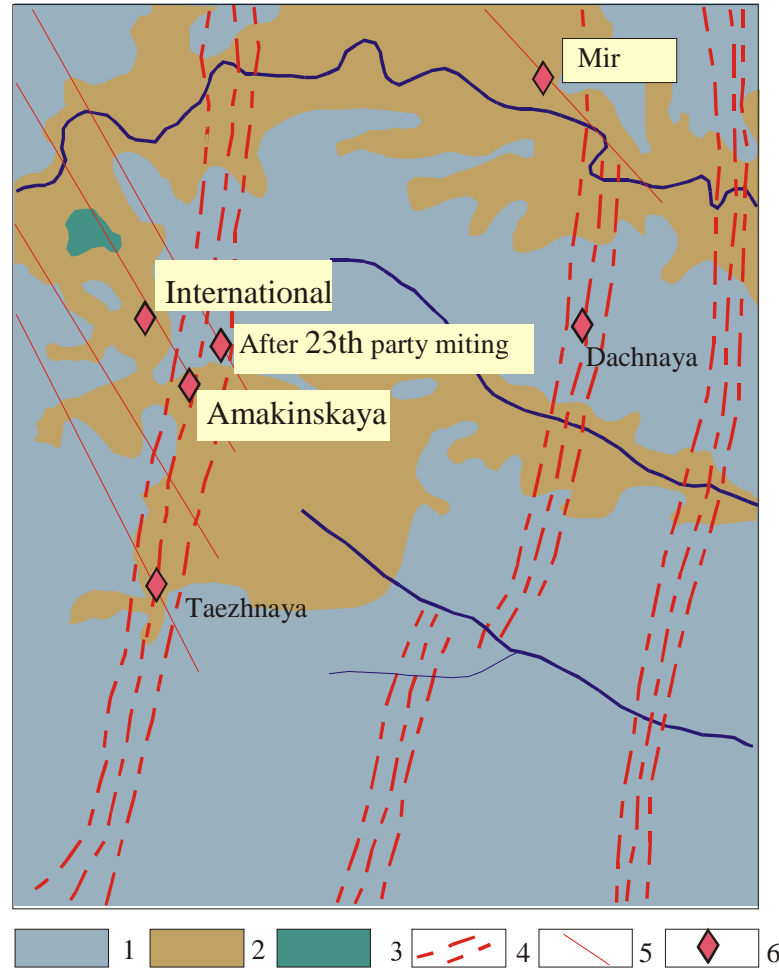

Figure 1. Schematic map of the Mirny kimberlite field 1. Lower Jurassic continental sediments. 2. Lower Paleozoic terrigenic-carboniferous rocks. 3. Basalts. 4. Regional faults. 5. feathering faults. 6. Kimberlite pipes 

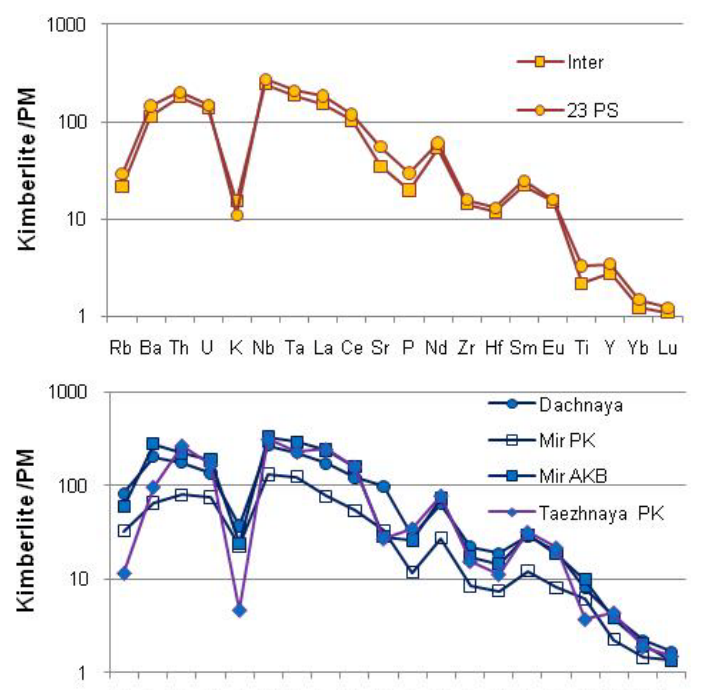

Rb BaTh U KNb Ta La Ce Sr P Nd Zr Hf SmEu Ti Y Yb Lu

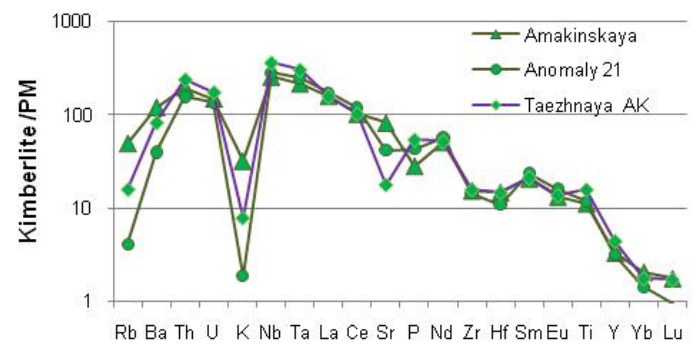

Figure 2. Primitive Mantle (PM) normalized trace elements patterns of Mirny field kimberlites. PM values after MackDonough and Sun (1995).

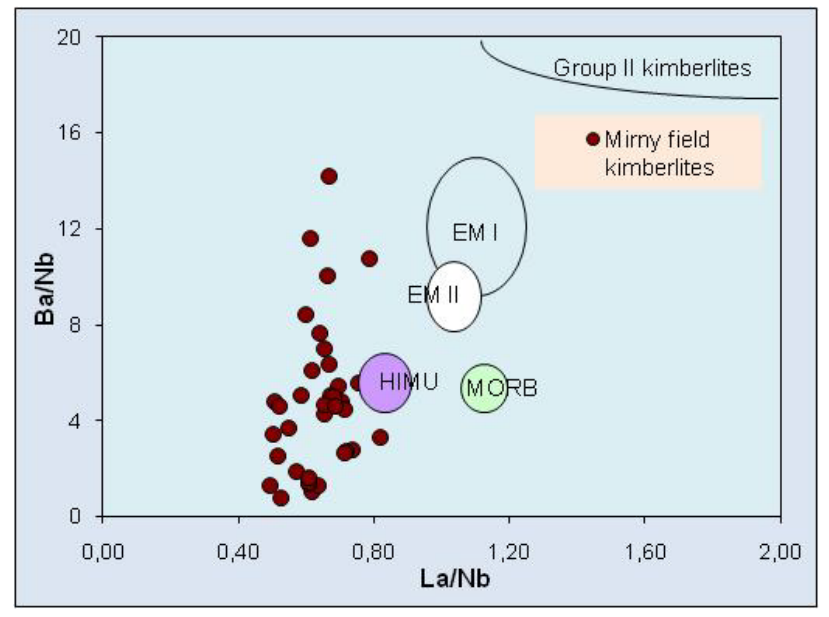

Figure 3. $\mathrm{La} / \mathrm{Nb}$ vs $\mathrm{Ba} / \mathrm{Nb}$ ratios diagram for Mirny field kimberlites. Compositional fields for MORB and OIB after Hofmann 1997.

Based on the chemical composition and mineralogy kimberlites of Mirny field could be subdivided into 3 groups. First group is kimberlites of Inter and 23PC, which have low $\mathrm{TiO}_{2}$ and $\mathrm{Fe}_{2} \mathrm{O}_{3}$ contents and very similar to each other geochemical composition. They contain a little of ilmenite and other minerals of low $\mathrm{Cr}$ megacrysts suite and are very rich in diamond.

Second group includes Mir, Dachnaya and Taezhnaya pipes. The Mir kimberlite pipe is one of the word biggest diamond deposits consists of two main varieties of kimberlites (PK and AKB), which systematically differs in their geochemical composition. AKB is enriched in all incompatible elements comparative to PK. Kimberlite of Dachnaya and Taezhnaya pipes are compositionally very similar to AKB of Mir pipe.

Kimberlites of Amakinskaya pipe, Anomaly 21 dyke and AK of Taezhnaya contain high amount of low $\mathrm{Cr}$ megacrysts, low diamond grade and are enriched in $\mathrm{TiO}_{2}, \mathrm{Fe}_{2} \mathrm{O}_{3}$ and $\mathrm{HFSE}$ relative to light and middle REE.

\section{Sr-Nd isotopes}

Initial Nd isotope ratios calculated back to time of Mirny field kimberlite emplacement ( $\mathrm{t}=360$ ma) show variable depletion relative CHUR model being 4 up to 6 of $\varepsilon N d t$ units, suggesting asthenospheric source for incompatible elements in kimberlites. On their Sr and Nd these kimberlites could be classified as group I, as the most of Siberian middle-Paleozoic kimberlites (Agashev et al, 2001). Sr isotope ratios are significantly variable, indicating complex source history and possible influence of postmagmatic alteration.

\section{Discussion}

Geochemical variations in kimberlite composition within one filed could be explained by combination of factors and first of all it is small scale heterogeneity of source. Kimberlite source region which located at the base of lithospheric mantle (Agashev et al, 2000, 2008) have a complex history. Magmas ascending from asthenosphere beneath could form the veined heterogeneously enriched source through fractional crystallization and metasomatism of adjacent peridotites. High temperature 
silicate metasomatism directly by asthenospheric magmas and precipitations of megacrysts suite is not favorable for diamond survival, but low-temperature metasomatism by residual volatile enriched melt probably favorable for diamond survival and grows. Parts of the source enriched in low-Cr megacrysts suite could be responsible for low diamond grade, $\mathrm{Ti}$ and $\mathrm{Fe}$ rich kimberlites like Amakinskaya pipe. Melts for diamond rich kimberlites of Inter and 23PC pipes could be formed from part of source experienced low-temperature metasomatism by residual $\mathrm{CO}_{2}$-rich melt. In melting of high volume kimberlite magma of Mir pipe probably diverse parts of source were involved and several batches of magma were formed.

The research was supported by the Russian Foundation for Basic Research, grants no. 15-0507758 and no. 16-05-00811 and by state assignment project (project No. 0330-2016-0006).

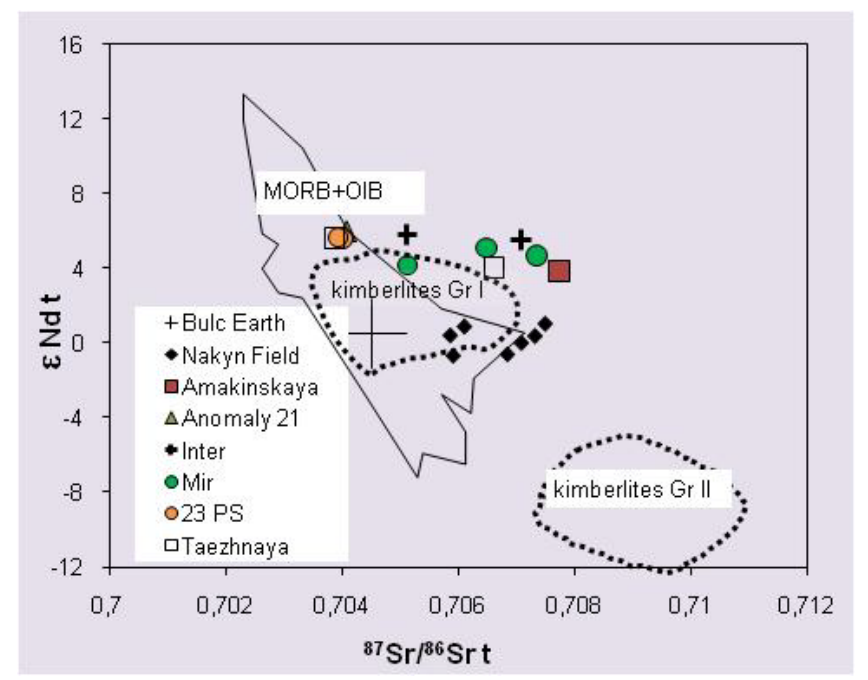

Figure 4. Sr and Nd isotope composition of Mirny field kimberlites. Compositional fields for MORB and OIB after Hofmann (1997). Nakyn field kimberlites after Agashev et al (2001). Kimberlites Group I and II after Smith (1983).

\section{References}

Agashev A.M., Orihashi Y., Watanabe T., Pokhilenko N.P and Serenko V.P. (2000). Sr and Nd isotope and geochemical features of Siberian Platform kimberlites. Russian Geology and Geophysics, v41, p.90-99.

Agashev A.M. Watanabe T. Bydaev D.A. Pokhilenko N.P. Fomin A.S. Maehara K. Maeda J. Geochemistry of kimberlites from the Nakyn field, Siberia: Evidence for unique source composition // Geology. - 2001. - Vol. 29. - № 3. - P. 267-270

Agashev A.M. Pokhilenko N.P. Takazawa E. McDonald J.A. Vavilov M.A. Watanabe T. Sobolev N.V. Primary melting sequence of a deep $(>250 \mathrm{~km})$ lithospheric mantle as recorded in the geochemistry of kimberlite-carbonatite assemblages, Snap Lake dyke system, Canada // Chemical Geology. - 2008. - Vol. 255. - № 3-4. - P. 317-328.

Hofmann, A.W., 1997, Mantle geochemistry: the message from oceanic volcanism: Nature, v. 385, p. 219-229.

McDonough, W.F., and Sun, S.-s.,1995, The composition of the Earth: Chemical Geology, v120, p. 223-253.

Smith, C.B., (1983), Pb, Sr and Nd isotopic evidence for sources of southern African Cretaceous kimberlites: Nature, v304, p. 51-54. 